\title{
Synergism between Hepatic Injuries and a Nonhepatotropic Reovirus in Mice Enhanced Hepatic Infection and Death
}

\author{
David A. Piccoli,“ Camillus L. Witzleben, ${ }^{\ddagger}$ Christine J. Guico, ${ }^{5}$ Allyson Morrison," and Donald H. Rubin" \\ ${ }^{*}$ Division of Gastroenterology and Nutrition, Children's Hospital of Philadelphia, Department of Pediatrics; ${ }^{\ddagger}$ Department of Pathology, \\ Children's Hospital of Philadelphia; "Research Medicine, Veterans Affairs Medical Center, Philadelphia,
}

Department of Microbiology, University of Pennsylvania School of Medicine, Philadelphia, Pennsylvania 19104

\begin{abstract}
Reovirus type 1, after intravenous inoculation in the adult mouse, is secreted via bile into the intestine in an infectious form. Although reovirus type 1 is rapidly removed from systemic circulation by the liver and the lung, very few hepatocytes express reovirus antigen during infection. In intestinal cells, reovirus replicates selectively in the crypts. This site preference may be due to active cell proliferation in the crypts. We hypothesized that the state of the cell may affect virus replication and tested this hypothesis by using chemical and surgical means to increase hepatic mitotic activity. Adult mice were treated with carbon tetrachloride or surgical trauma, inoculated with reovirus type 1 intravenously, and subsequently killed. Virus antigen was identified using a highly specific immunohistochemical technique. Liver sections were stained using immunoperoxidase with specific rabbit antireovirus antibody. Hepatotoxin and surgical trauma increase reovirus antigen detection in both Kupffer cells and hepatocytes. Only the sequential administration of $\mathrm{CCl}_{4}$ and virus caused mortality at doses sublethal for each alone. These data demonstrate a synergism between hepatic injury and reovirus which results in a significant increase in the magnitude of viral infection and contributes to mortality. Such synergism may be important in idiopathic liver disease. (J. Clin. Invest. 1990. 86:1038-1045.) Key words: hepatitis • viral hepatitis • carbon tetrachloride • liver regeneration $\bullet$ hepatotoxins
\end{abstract}

\section{Introduction}

Reoviruses infect animals, including man, via an enteric route $(1,2)$. After entry through $\mathbf{M}$ cells, reovirus may infect other organ systems (3). The site and outcome of reovirus disease depends on the serotype of the virus, the inoculum size, and the age of the host (4-6). In individual organs, site specific infection has been recognized $(5,7)$. We have shown that reovirus type 1 infects crypt cells within the ileum, but mature villus cells do not become productively infected (5). For both crypt and villus epithelial cells, virus-specific receptors are present on the basolateral surface (8). Therefore, virus infec-

Address reprint requests to D. H. Rubin, Research Medicine (151F), VAMC, University and Woodland Aves., Philadelphia, PA 19104.

Received for publication 21 November 1989 and in revised form 9 April 1990.

J. Clin. Invest.

(C) The American Society for Clinical Investigation, Inc.

0021-9738/90/10/1038/08 $\$ 2.00$

Volume 86, October 1990, 1038-1045 tion is not dependent merely upon the capacity of the virus to bind to the intestinal cell. This finding suggests that reovirus replication is restricted to replicating epithelial cells at a step after binding of virus.

After entry into the host, systemic virus is rapidly cleared by the lung and the liver (9). Our studies have shown that reovirus type 1 can pass into the bile in an infectious form during systemic infection (10). However, few hepatocytes have evidence of antigen at times when virus can be found within the bile, and hepatic infection has not been reported as a significant component of systemic infection with reovirus type $1 / \mathrm{L}$ in suckling mice (11).

Reovirus causes hepatobiliary infection in the neonatal mouse, with hepatocellular necrosis (12). Reovirus type 1 replication within the adult liver may be restricted in a manner analogous to intestinal epithelial cells. Since the mature liver has a low mitotic index, an enhancement of hepatocellular replication might increase reovirus antigen expression.

To examine whether the state of the hepatocyte affects reovirus replication an hepatotoxin, carbon tetrachloride $\left(\mathrm{CCl}_{4}\right)$ or surgery were used to increase the mitotic index of hepatocytes. Carbon tetrachloride causes a P-450-mediated lipid peroxidation of the endoplasmic reticulum and also results in covalent binding of $\mathrm{CCl}_{4}$ metabolites, resulting in a centrizonal necrosis and subsequent regeneration (13). The replication begins within $12 \mathrm{~h}$ and peaks at $48-72 \mathrm{~h}$ after $\mathrm{CCl}_{4}$ administration (14-16). Hepatic resection of 30-70\% results in a marked increase in the hepatic mitotic index from $15-36 \mathrm{~h}$ later (17), without zonal necrosis. Both methods have been shown to result in regeneration, production of alpha-fetoprotein, polyamines, changes in hormone receptors, and expression of cellular oncogenes. Similarly, induced focal injury has been shown to increase the proliferation of local Ito cells and hepatocytes adjacent to the areas of damage, but not in other uninjured lobes (18).

The experiments presented here demonstrate that these methods of hepatic insult increase the expression of reovirus antigen in the liver. Furthermore, pretreatment of animals with sublethal doses of $\mathrm{CCl}_{4}$ and reovirus type 1 results in a profound increase in mortality, which is uniquely dependent on the time course of their administration.

\section{Methods}

Mice

Adult female A/J mice (Jackson Laboratory, Bar Harbor, ME), 5-7 wk old, were fed a house diet (Ralston-Purina Corp., St. Louis, MO) and water ad lib. and maintained in an animal facility with a controlled light/dark cycle. Viral experiments were conducted in separate facilities, and there was no evidence of humoral response to reovirus in the mice before experimentation. 


\section{Purification of reovirus}

Reovirus type 1/Lang (1/L) was obtained and prepared as previously described (19). For mouse inoculation, a stock of reovirus that was passed twice in $\mathrm{L}$ cells was purified by substituting ultrasonic disruption (Ultrasonic 200; Branson Sonifiers, Danbury, CT) for cell homogenization in a modification of previously described techniques (20). The ratio of viral particle to plaque-forming unit (pfu) was $\sim 100: 1$ (21). Assay of viral PFU was performed as previously described (5).

\section{Inoculation of virus}

Mice were inoculated intravenously via the tail vein with $\sim 10^{11}$ particles of reovirus type $1 / \mathrm{L}$ (determined by the optical density of the suspension) suspended in $0.1 \mathrm{ml}$ of PBS.

\section{$\mathrm{CCl}_{4}$ administration}

$0.1 \mathrm{ml}$ of a 1:1 mixture of carbon tetrachloride/olive oil was gavage fed under light methoxyflurane anesthesia (Pitman-Moore Inc., Washington Crossing, NJ) either $4(\mathrm{D}-4)$ or $2 \mathrm{~d}(\mathrm{D}-2)$ before, or simultaneously with (D0), the inoculation of virus.

\section{Collection of samples and viral assay}

Mice were killed and processed immediately for pathology and viral titer assay. In animals where bile was sampled, mice were first anesthetized with intraperitoneal pentobarbital $(50 \mathrm{mg} / \mathrm{kg}$ i.p.) and the common duct was cannulated with PE-10 tubing (Clay-Adams Div., Parsippany, NJ) for $30 \mathrm{~min}$ before killing. Bile was frozen and stored at $-70^{\circ} \mathrm{C}$ before assay. Blood, duodenum, ileum, liver, spleen, and lung were collected on ice for viral assays and frozen at $-70^{\circ} \mathrm{C}$. Specimens of intestinal tissues were collected and assayed as previously described (5). All samples of tissue were frozen and thawed three times, disrupted by ultrasound (Ultrasonic 200; Branson Sonifiers) and assayed on L cell monolayers in 12-well cluster plates (Costar Corp., Cambridge, MA). The concentration of protein in the liver specimens was determined by a modification of the method of Lowry et al. (22) for use in microtiter plates.

\section{Histologic and morphometric methods}

Liver tissues were immediately fixed in Bouin's solution for $3 \mathrm{~h}$, dehydrated in a graded series of ethanols and embedded in paraffin blocks. Sections were cut at 3-4 $\mu \mathrm{m}$ on a rotary microtome (American Optical, Buffalo, NY). These sections were stained with hematoxylin and eosin and with our modification of the avidin-biotin method of immunoperoxidase stain. The immunoperoxidase stain involved the use of xylene and a graded series of ethanols to rehydrate the liver tissues, and a methanol-hydrogen peroxide solution was used to block endogenous peroxidase. Normal goat serum (Vector Laboratories, Burlingame, CA) was used to block nonspecific binding in the tissue. Rabbit derived polyclonal reovirus antibodies that have previously been described $(9$, 10) (D. H. Rubin, Veterans Affairs Hospital, Philadelphia, PA) served as primary antibody, with goat anti-rabbit sera (Vector Laboratories) as secondary antibody enhanced by an avidin-biotin complex (Vector Laboratories) (23). Sections were developed with diaminobenzidene chromogen, with hematoxylin solution for counterstaining.

Using Sigma Scan (Jandel, Corte Madera, CA) and a light microscope with a square marked eyepiece divided into a 10 by 10 grid, the following measurements and counts were performed: area of each liver section, areas of necrosis in each section, percent necrosis, and number of hepatocytes per grid. These were used to determine the total number of viable hepatocytes. For each animal, an area containing $\sim 30,000$ cells was counted. The positive immunoperoxidase cells were identified as either hepatocytes, Kupffer cells or cells of indeterminate type, and expressed per 1,000 hepatocytes.

\section{Animal groups}

Effect of the timing of $\mathrm{CCl}_{4}$ administration on reovirus infection. Adult A/J mice were divided into four groups ( $n=12-18$ per group). The control group received only reovirus, while the three experimental groups were given $\mathrm{CCl}_{4} 4,2$, or $1 \mathrm{~d}(\mathrm{~s})$ before, or simultaneously with, intravenous inoculation with $10^{9} \mathrm{pfu}\left(10^{11}\right.$ particles) of reovirus type $1 / \mathrm{L}$. To eliminate intergroup variability, reovirus inoculation was performed on the same day on all groups, and the time recorded as day $=0$. One group of mice was killed at $2 \mathrm{~d}$ after inoculation for viral assays and morphometric analysis. A second group of mice $(n=18)$ was followed for $4 \mathrm{~d}$ postinoculation to monitor mortality.

Dose of viral inoculum after $\mathrm{CCl}_{4}$ administration necessary to produce mortality. Mice were given $\mathrm{CCl}_{4} 2 \mathrm{~d}$ before an intravenous inoculation of either $10^{9} \mathrm{pfu}\left(10^{11}\right.$ particles), $10^{8} \mathrm{pfu}\left(10^{10}\right.$ particles), or $10^{7}$ pfu ( $10^{9}$ particles) and surviving mice were killed at $4 \mathrm{~d}$ postinoculation. The effects of viral inoculum on morbidity, mortality, hepatic histopathology, and viral titers were recorded.

Effect of hepatic trauma and hepatic regeneration on viral antigen expression in the liver. 16 mice underwent laparotomy with pentobarbital anesthesia. Mice were divided into three groups: (a) 50\% hepatic resection, $(b)$ blunt trauma to one lobe of liver, or $(c)$ sham-operated control mice. Hepatic resection was performed with removal of three lobes of liver and suture ligation of the lobar pedicle. These mice received water containing $20 \%$ glucose (wt/vol) for $2 \mathrm{~d}$. For the experimental mice receiving blunt trauma, the large median lobe of the liver was identified and compressed three times with a pair of blunt forceps to produce a small hematoma. For control mice, the abdomen was opened but the liver was not manipulated, and the abdomen was closed.

All three groups were then inoculated with $10^{9} \mathrm{pfu}$ of reovirus type 1/L. Two days postinoculation the mice were killed, and the entire traumatized "local" lobe and a right "distal" lobe were fixed for processing. Necrotic areas adjacent to the site of trauma were excluded from analysis.

\section{Liver function tests}

Serum was obtained from groups of five mice inoculated with virus, virus plus $\mathrm{CCl}_{4}$, or $\mathrm{CCl}_{4}$ alone at 6-h intervals after toxin and virus challenge. Liver functions tests included albumin, alanine aminotransferase (ALT), ${ }^{1}$ aspartate aminotransferase (AST), bilirubin, and total protein, and were performed on Ektachem autoanalyzer (EastmanKodak Co., Rochester, NY) using standard automatic methods.

\section{Statistics}

Groups of mice were analyzed by analysis of variance and independent two tailed $t$ tests. Liver function tests obtained from serum specimens from groups of mice were analyzed for significance by Chi-square. Statistical significance was $P<0.05$.

\section{Results}

Hepatotoxin exposure increases reovirus antigen expression in both Kupffer cells and hepatocytes. In the livers of mice given virus alone, there was no histologic hepatitis, and $\sim 1 \%$ of hepatocytes expressed reovirus antigen (Fig. 1, $A$ and $B$ ). Mice treated with $\mathrm{CCl}_{4}$ alone demonstrated zone 3 necrosis, but no immunoperoxidase positive staining. All mice receiving $\mathrm{CCl}_{4}$ and virus showed a significant increase in the expression of reovirus antigen in both hepatocytes (Figs. $1 D$ and $2 A$ ) and Kupffer cells (Fig. $2 B$ ). Significant differences in hepatocyte immunoperoxidase staining existed among all experimental groups compared to the control group $(P<0.0001)$. In addition, the group of mice treated with $\mathrm{CCl}_{4} 2 \mathrm{~d}$ before inoculation of virus was significantly different when compared to the other experimental groups $(P<0.02$, Fig. $2 A)$. The results for

1. Abbreviations used in this paper: ALT, alanine aminotransferase; AST, aspartate aminotransferase; $\mathrm{CCl}_{4}$, carbon tetrachloride. 

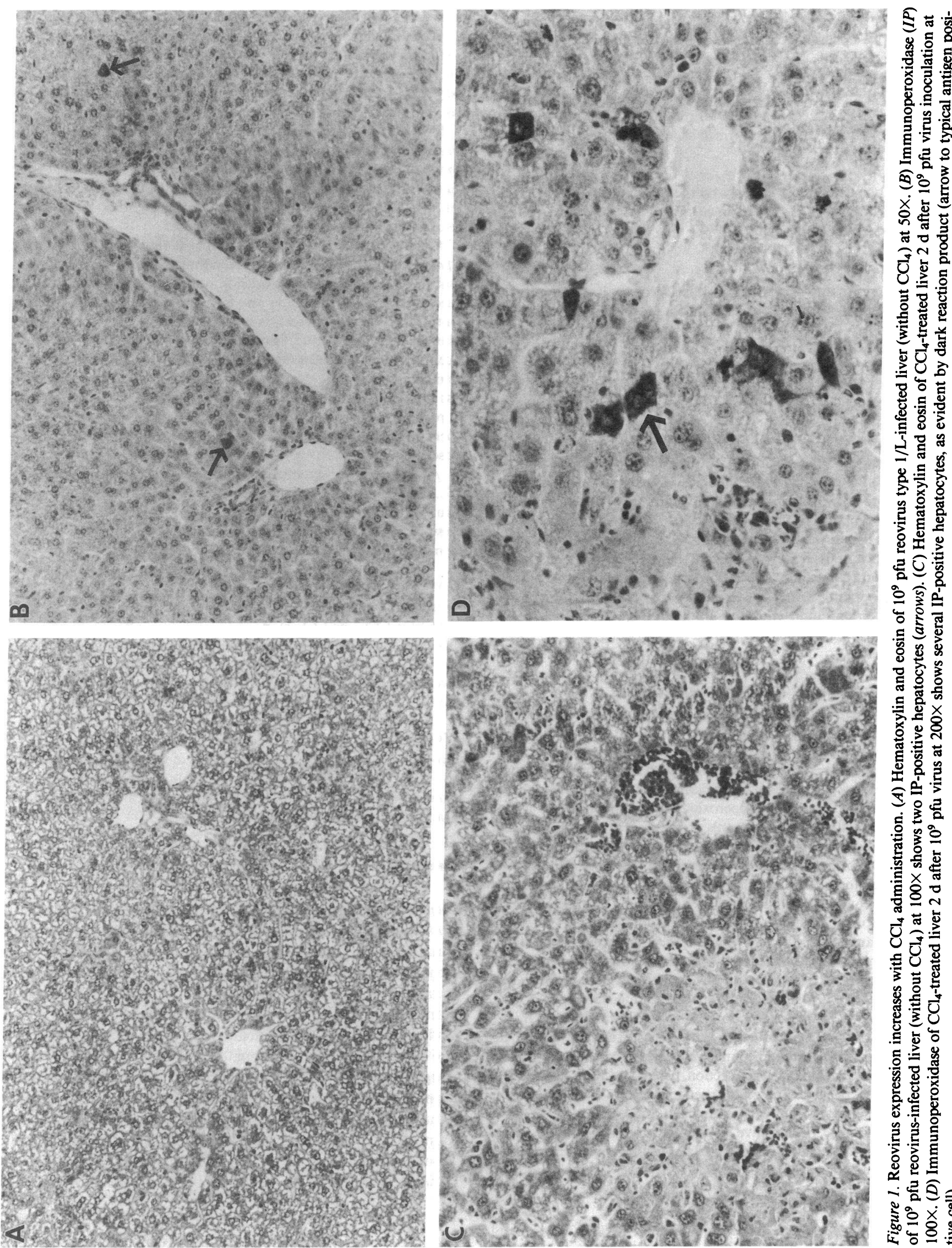

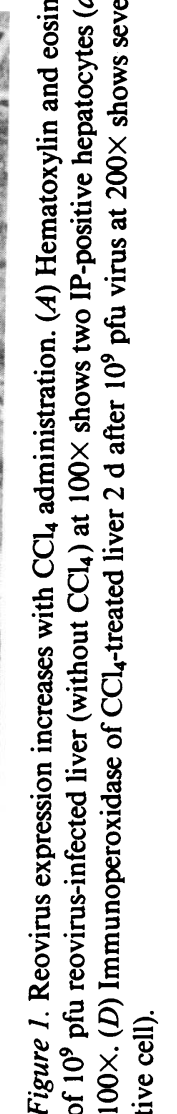




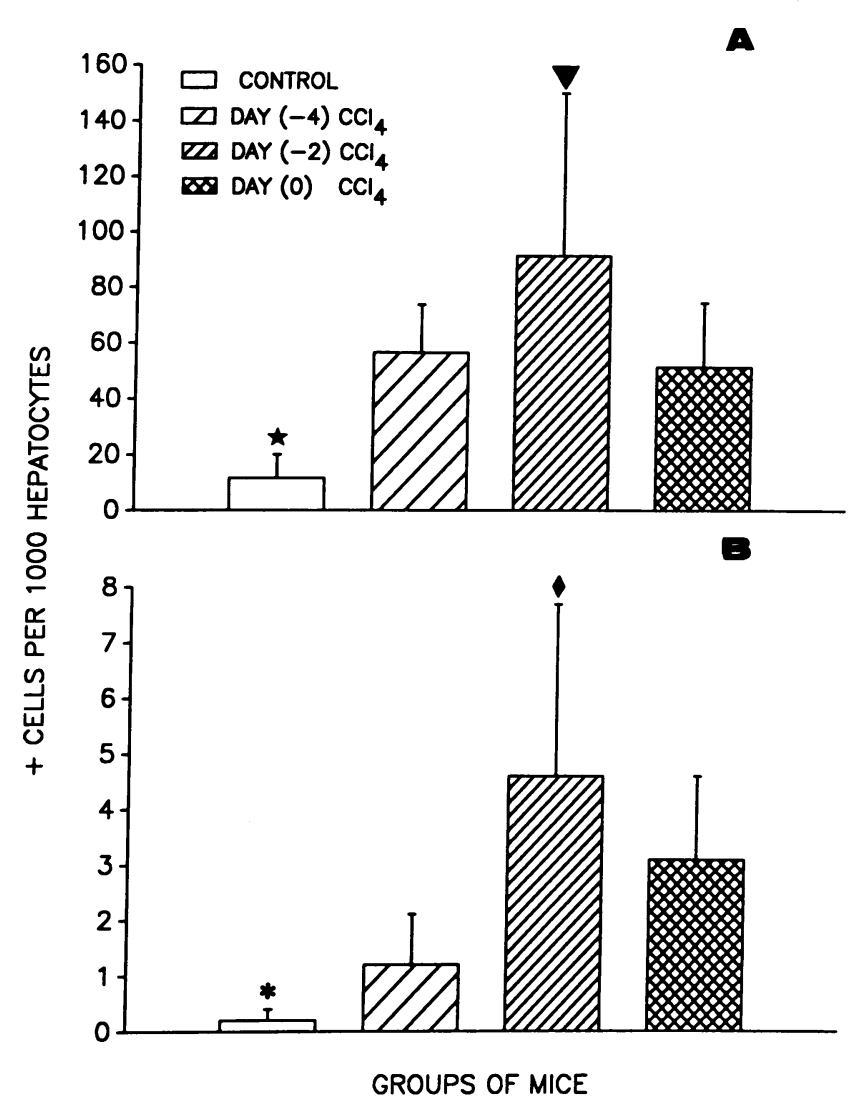

Figure 2. Reovirus antigen-positive cells. Adult $\mathrm{AJ}$ mice were divided into four groups ( $n=10-18$ per group). Three groups of adult $\mathrm{AJ}$ mice were gavage fed with $\mathrm{CCl}_{4} 4 \mathrm{~d}$ or $2 \mathrm{~d}$ before, or simultaneously with intravenous inoculation with $10^{9} \mathrm{pfu}$ of reovirus type 1 . Controls received reovirus only. Mouse livers were examined $2 \mathrm{~d}$ after inoculation for reovirus antigen by immunoperoxidase staining. Immunoperoxidase positive cells were identified with a light microscope and Sigma scanner. $(A)$ Hepatocytes: Comparison of groups $D(-4)$, $\mathrm{D}(-2)$, and $\mathrm{D}(0)$ vs. control were significant at $P<0.0001(\star)$, and $\mathrm{D}(-2)$ vs. either $\mathrm{D}(-4)$ or $\mathrm{D}(0)$ were significant at $P<0.02(\mathrm{v})$. (B) Kupffer cells: comparison between groups $D(-4), D(-2)$, or $D(0)$ vs. control were significant at $P<0.001(*)$, and $\mathrm{D}(-2)$ vs. $\mathrm{D}(-4)$ or $\mathrm{D}(0)$ were significant at $P<0.01(\bullet)$.

Kupffer cells were similar to those seen in hepatocytes, with the maximal increase in reovirus antigen positive Kupffer cells being present in mice pretreated with $\mathrm{CCl}_{4} 2 \mathrm{~d}$ before virus inoculation $(P<0.001$ and $P<0.01$ versus controls and other experimental groups, respectively, Fig. $2 \mathrm{~B}$ ).

Reovirus virions are present in Kupffer cells by electron microscopic analysis. By electron microscopy, intact virions could be readily identified in Kupffer cells of mice receiving pretreatment $\mathrm{CCl}_{4} 2 \mathrm{~d}$ before reovirus administration (Fig. 3 $A$ ). Despite a 10-fold higher magnitude of antigen-positive hepatocytes as compared with Kupffer cells, it was difficult to identify intact virions in hepatocytes. In $\mathrm{CCl}_{4}$-treated livers, hepatocytes were, however, identified that demonstrate unusual cytoplasmic inclusions containing coarse filamentous and/or floccular material. (Fig. $3 \mathrm{~B}$ ).

Titers of infectious reovirus type 1 are increased with hepatotoxin exposure. With respect to viral titers, there was no difference in the low titers of reovirus in the spleen, colon, ileum, blood, or lung, or in the relatively high titer found in bile between experimental groups and controls (Table I). However, there was a $1.8 \log _{10}$ increase in the viral titers assayed from experimental mouse livers $(P<0.01$, Table $\mathrm{I})$, which is similar to the immunoperoxidase findings.

Surgical trauma increases reovirus antigen expression in the traumatized liver lobe. Discrete surgical trauma caused an increase in the reovirus antigen demonstrated in hepatocytes and Kupffer cells in areas separate from the regions of necrosis. This difference was evident only in the local lobe that received the trauma, and only in mice operated either $4 \mathrm{~d}$ before or on the day of inoculation (Fig. 4, $A$ and $B$, respectively). In these groups, the magnitude of the effect was similar to that seen with $\mathrm{CCl}_{4}$.

Hepatotoxin exposure increases morbidity and mortality. All mice treated with $\mathrm{CCl}_{4}$ lost similar amounts of weight in the first $2 \mathrm{~d}$ after administration. Mice treated with $\mathrm{CCl}_{4} 2 \mathrm{~d}$ before virus had the most dramatic weight loss, with the survivors being significantly lighter than the mice in the other groups $(P<0.01$, data not shown).

Mortality was observed only in the mice that received $\mathrm{CCl}_{4}$ 1 or $2 \mathrm{~d}$ before $5 \times 10^{8}$ to $10^{9}$ pfu inoculation, with $75-100 \%$ of mice dying, depending upon experiment. Other sequences never resulted in mortality.

Liver function tests performed on sera from groups of mice that received reovirus type 1 plus $\mathrm{CCl}_{4}$ had significantly higher AST and ALT levels $(P<0.0001)$ at $30 \mathrm{~h}$ after virus infection than mice that received $\mathrm{CCl}_{4}$ or reovirus alone (Table II). Total protein, albumin and bilirubin were not significantly different between the groups at multiple time points $(6-30 \mathrm{~h})$ after virus infection.

Since reovirus antigen detection was greatest in mice pretreated with $\mathrm{CCl}_{4} 2 \mathrm{~d}$ before inoculation, three groups of $\mathrm{CCl}_{4}$ pretreated mice were inoculated with either $10^{7}, 10^{8}$, or $10^{9} \mathrm{pfu}$ reovirus and were observed for $4 \mathrm{~d}$. A significant increase in mortality was only seen in the group of mice receiving the highest inoculum. In this group, mortality began at day 2 and

Table I. Effect of $\mathrm{CCl}_{4}$ Given $2 \mathrm{~d}$ before Reovirus on Titers of Virus in Bile, Blood, Liver, Spleen, Lung, and Intestine, $2 \mathrm{~d}$ after $10^{9} \mathrm{pfu}$ Inoculation (Controls $n=18$, Experimentals $n=36$ )

\begin{tabular}{lccc}
\hline $\begin{array}{c}\text { Organ or } \\
\text { body fluid }\end{array}$ & Controls & Experimentals & Significance \\
\hline & \multicolumn{2}{c}{$\begin{array}{c}\text { pfu/g or } m l\left(\log _{10}\right) \\
\text { (mean } \pm S D)\end{array}$} \\
Bile & $3.2 \pm 1.3$ & $2.9 \pm 1.8$ & NS \\
Blood & $1.7 \pm 2.0$ & $1.3 \pm 1.7$ & NS \\
Liver & $1.1 \pm 1.4$ & $2.9 \pm 1.2$ & $P<0.01^{*}$ \\
Spleen & $0.4 \pm 0.2$ & $0.8 \pm 0.6$ & NS \\
Lung & $0.3 \pm 0.1$ & $0.3 \pm 0.3$ & NS \\
Ileum & $0.4 \pm 0.3$ & $0.5 \pm 0.4$ & NS \\
Colon & $0.5 \pm 0.3$ & $0.7 \pm 0.9$ & \\
\end{tabular}

The titer of reovirus $1 / \mathrm{L}$ was determined by plaque assay on specimens of bile, blood, liver, spleen, lung, and intestine $2 \mathrm{~d}$ after inoculation of $10^{9} \mathrm{pfu} \mathrm{IV} \mathrm{in} \mathrm{CCl}_{4}$ treated or control mice (control, $n=18$, experimentals, $n=36$ ).

* Significance determined by $t$ test. 


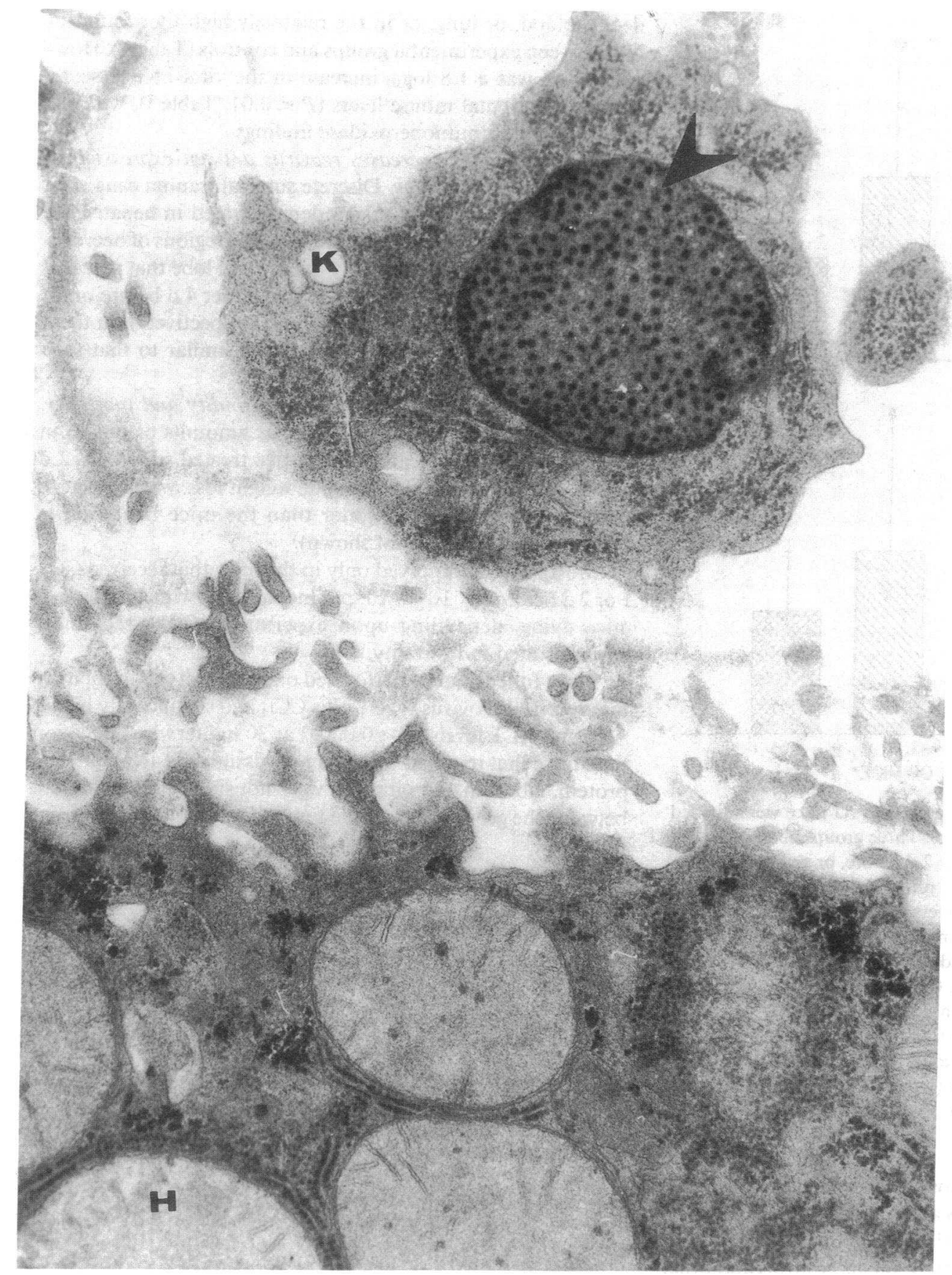

Figure 3. Electron microscopic (EM) localization of reovirus virions in liver. Mice were fed with $\mathrm{CCl}_{4}$ and $2 \mathrm{~d}$ later injected intravenously with $10^{9} \mathrm{pfu}$ reovirus 1/L. Specimens were obtained for EM $48 \mathrm{~h}$ after viral inoculation. $(A)$ EM of Kupffer cell $(K)$ with virions in its cytoplasm (see arrow, 7,000 $\times)$, $H$ hepatocyte $(B)$ Accumulation of amorphous material in the cytoplasm of hepatocytes is evident in this representative EM of a hepatocyte with filamentous and floccular material (A) $(7,500 \times)$. (Inset) This material does not contain complete virions $(15,000 \times)$ Hepatocyte mitochondria $(M)$ are evident. peaked at day 3 . Observation of mice for as long as 2 wk after inoculation did not result in any increase in mortality.

\section{Discussion}

Despite the previous demonstrations that the liver plays a role in clearance of systemic reovirus (9), and that the virus is excreted in bile (10), only small numbers (1\%) of hepatocytes contain reovirus type 1 2-4 d after inoculation. This indicates that the hepatocytes do not normally support replication of reovirus type $1 / \mathrm{L}$.

The experiments reported here demonstrate that when the liver is perturbed in a variety of ways there is an increased and prolonged expression of virus in both hepatocytes and littoral lining cells. The increase in littoral cell expression of virus may indicate interference with clearance of virus from these cells, recruitment of additional cells to become infected, enhanced proliferation of virus within individual cells, or some combination of these processes. In any case, these cells become a reservoir for virus and for continued exposure of hepatocytes to virus. It is less likely that an increase in enterohepatic circulation explains the persistence of infected Kupffer cells since we were unable to demonstrate increases in content of infectious virus in either bile or intestinal lumen.

Even with the increased expression of viral antigen, visual- 


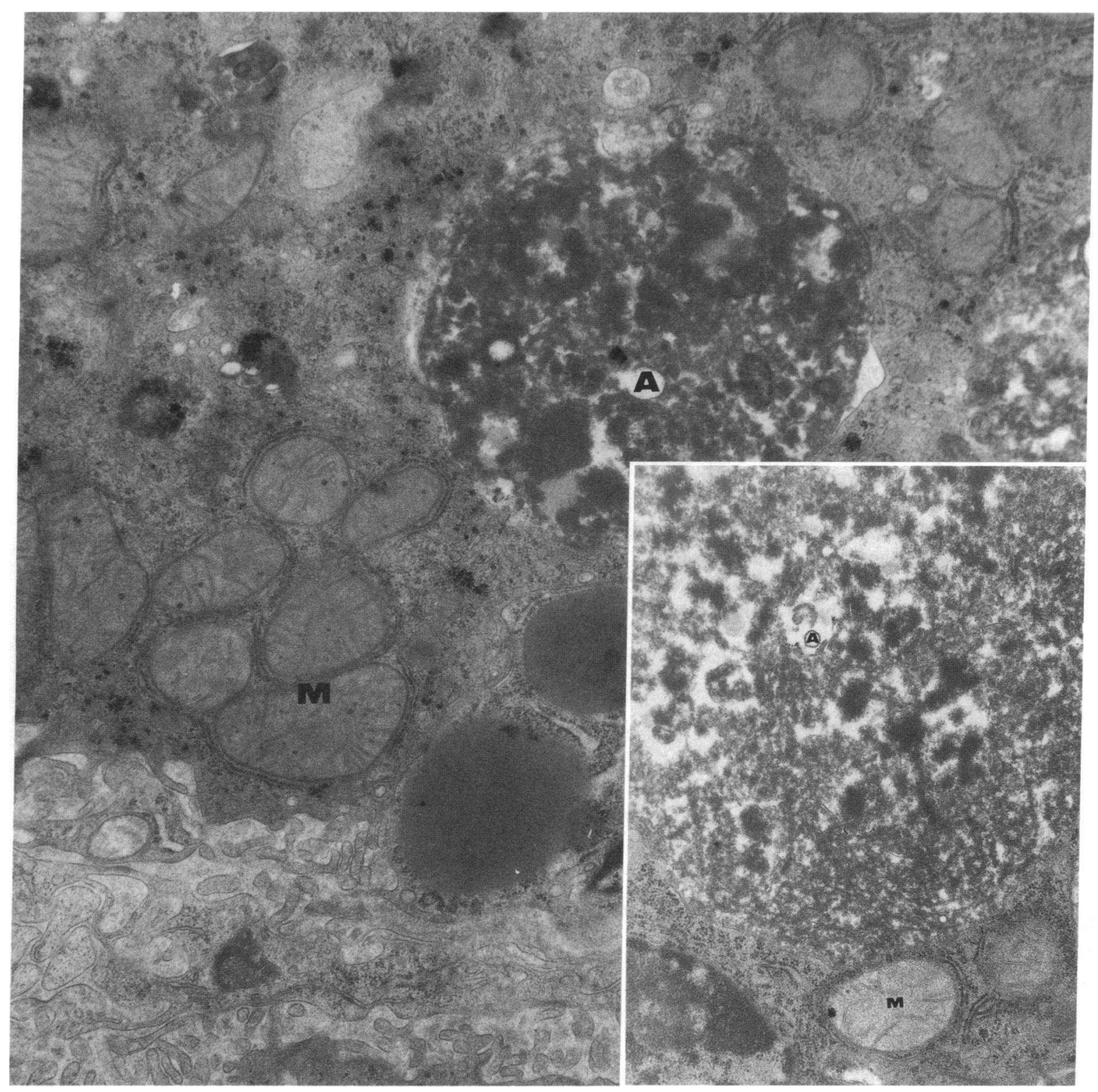

Figure 3 (Continued)

ized by immunoperoxidase staining, we were unable to identify intact virions in hepatocytes by electron microscopy. We suspect the unusual cytoplasmic inclusions demonstrated in Fig. $3 B$ may represent viral protein, and are investigating this possibility via immunoelectron microscopy. These results suggest that reovirus antigen expression may not represent complete assembly of infectious virus in some cell types (i.e., hepatocytes). Furthermore, this suggests that the increased titers of virus found in mouse livers stimulated to express reovirus antigen by co-administration of $\mathrm{CCl}_{4}$ may be due to enhanced production of virions by Kupffer cells.

There are a number of mechanisms that might be responsible for the enhanced expression of reovirus associated with these liver perturbations. It is unlikely that alterations in membrane fluidity or permeability associated with $\mathrm{CCl}_{4}$ accounts for enhanced reovirus antigen expression since the toxin was effective even when given 4 days prior to virus.
Other mechanisms to account for increases in reovirus expression include the following: (a) that increases in the number or avidity of cell membrane receptors for reovirus occur with hepatic insult; or $(b)$ that reovirus antigen expression requires a replicating or activated cell. In vitro, Duncan et al. (24) have suggested that transformed cells are more capable of replicating virus than nontransformed cells. Their experiments suggested that reovirus infection might be enhanced during increased cell turnover, in a manner not related to virus receptor alterations. Studies are in progress to examine which factors influence reovirus replication and antigen expression in vivo.

The basis of the enhanced mortality in one group of $\mathrm{CCl}_{4} /$ reovirus treated mice is similarly unclear. A synergism between non-lethal doses of reovirus type $1 / \mathrm{L}(6)$ and $\mathrm{CCl}_{4}$ resulted in lethal disease only when virus was given 1 or $2 \mathrm{~d}$ after toxin. This time course coincides with the known peak of mitotic activity in hepatocytes after a single dose of $\mathrm{CCl}_{4}(14)$. 
There was not a dramatic increase in the number of necrotic cells in mice inoculated with $\mathrm{CCl}_{4}$ and reovirus, simultaneously or $2 \mathrm{~d}$ later. These results suggest that the enhanced mortality was not due to liver cell necrosis per se. However, tests of hepatocellular damage, AST and ALT, were significantly increased in the groups of mice that received $\mathrm{CCl}_{4} /$ virus compared with other groups of mice. These data may be in keeping with the observations from other viral systems that viral antigen can cause significant cellular disruption without cell lysis (25-27).

Alternatively, it is possible that infection of the littoral cells (Ito, natural killer [Pit], and Kupffer) influence survival. We have not demonstrated reovirus infection in either Ito or Pit cells. However, Ito and Pit cells may have a role in either recovery from toxin injury or viral infection, respectively (28-31), and therefore either may play a role in the enhanced susceptibility to reovirus infection. A role for Kupffer cells is more likely in our model, since this cell type is clearly infected. Moreover, infection limited to Kupffer cells with frog virus 3 has been shown to result in a fatal hepatitis (32). More recent studies have suggested that macrophage products such as leukotriene B4 may directly lead to hepatocellular damage in the frog virus 3 model (33). Indeed, our inability to find intact

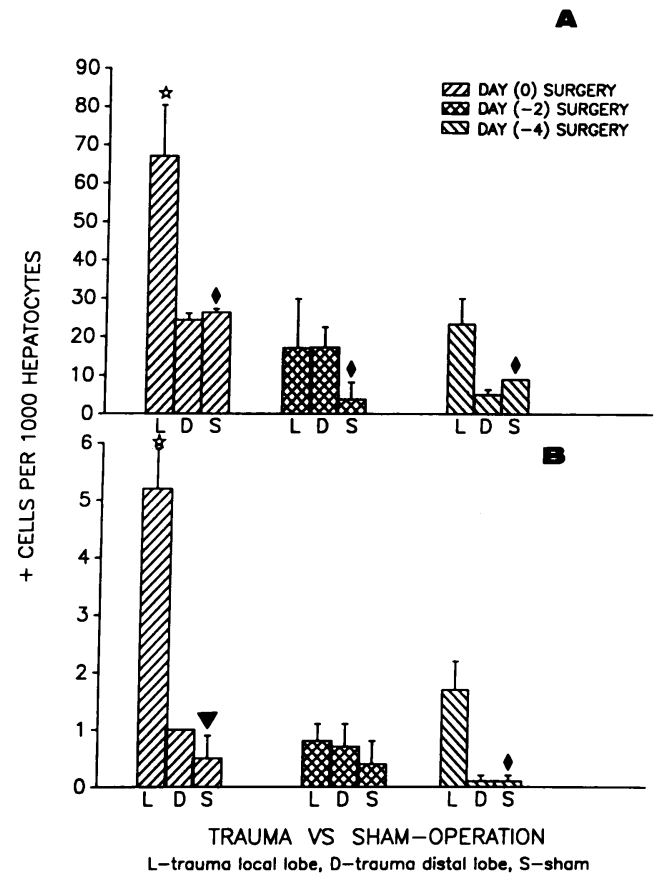

Figure 4. Reovirus antigen positive cells after hepatic trauma. Six groups of adult $\mathrm{AJ}$ mice ( $n=5-9$ per group) were subjected to surgery consisting of trauma to the left liver lobe $4 \mathrm{~d}$ or $2 \mathrm{~d}$ before, or simultaneously with intravenous injection of $10^{9}$ pfu type 1 reovirus. Control mice only had a sham operation. The main left lobe of the mouse livers and another lobe distal to the trauma site were examined $2 \mathrm{~d}$ after inoculation for virus antigen. Immunoperoxidase positive cells were identified with a light microscope and Sigma scanner. $(A)$ Hepatocytes: Comparison between trauma site counts of group $D(0)$ vs. groups $(D-2)$ and $D(-4)$ were significant at $P<0.05$ ( $\star$ ). All trauma local lobes vs. all sham operated groups were significant at $P<0.01(\bullet)$. (B) Kupffer cells: Comparison between trauma site counts of group $\mathrm{D}(0)$ vs. groups $\mathrm{D}(-2)$ or $\mathrm{D}(-4)$ were significant at $P$ $<0.01(\star)$. $D(0)$ trauma local lobes vs. $D(0)$ sham-operated lobes were significant at $P<0.0001(\nabla)$.
Table II. Effect of Reovirus and $\mathrm{CCl}_{4}$ on Liver Function

\begin{tabular}{|c|c|c|c|c|c|}
\hline & \multicolumn{5}{|c|}{ Liver function tests } \\
\hline & AST & ALT & Alb & TP & BR \\
\hline & \multicolumn{2}{|c|}{ U/liter } & \multicolumn{2}{|c|}{$g / d l$} & $m g / d l$ \\
\hline Virus & 505 & 262 & 3.0 & 5.0 & 0.7 \\
\hline $\mathrm{CCl}_{4}$ & 711 & 507 & 3.0 & 5.4 & 0.7 \\
\hline $\mathrm{CCl}_{4} /$ virus & $1498^{*}$ & $705^{*}$ & 2.5 & 4.6 & 0.9 \\
\hline
\end{tabular}

Groups of five mice were bled at various times after intravenous inoculation of virus or feeding of $\mathrm{CCl}_{4}$. Reovirus was inoculated $48 \mathrm{~h}$ following $\mathrm{CCl}_{4}$ in mice that received both treatments. Liver function tests obtained include: AST, ALT, albumin (ALB), total protein (TP), and bilirubin (BR). At $78 \mathrm{~h}$ after $\mathrm{CCl}_{4}$ feeding or $30 \mathrm{~h}$ after virus inoculation, significant differences in AST and ALT were present in mice that received $\mathrm{CCl}_{4}$ plus reovirus type 1 compared with mice that received $\mathrm{CCl}_{4}$ or virus alone. ${ }^{*} \chi^{2}$ significance $=P<0.0001$.

virions in the hepatocytes may indicate a central role for Kupffer cells in the pathogenesis of this disease.

This model demonstrates a synergism between a common nonhepatitis virus and a hepatotoxin and other hepatic perturbations. Other studies have shown that humans with chronic liver disease may have increased antibody titers to reovirus (34-36), although the significance of these findings is unclear. This question should perhaps be revisited, since our findings raise the theoretic possibility that infection with reovirus, or some other nonpathogenic virus, may induce pathologic lesions in the liver of individuals with acute or chronic hepatic insults (e.g., alcohol injury).

\section{Acknowledgments}

We wish to thank M. I. Greene, E. Eisenberg, C. Cuff, S. Ling, and G. Feldman as assessed for critical review of this manuscript.

This work was supported by a grant from Veterans Affairs. D. H. Rubin was supported by a Career Development Award from Veterans Affairs. C. J. Guico was supported by a grant from the Foderer Foundation. D. A. Piccoli is supported by a National Institutes of Health General Clinical Research Center Program Clinical Associate Physician Award, (M01-RR00240-25S1), and by a grant from the Heinz Foundation Nutrition Center.

\section{References}

1. Rosen, L., and F. R. Abinanti. 1960. Natural and experimental infection of cattle with human types of reoviruses. Am. J. Hyg. 71:250-257.

2. Wolf, J. L., D. H. Rubin, R. Finberg, R. S. Kauffman, A. H. Sharpe, J. S. Trier, and B. N. Fields. 1981. Intestinal M cells: a pathway for entry of reovirus into the host. Science (Wash. DC). 212:471-472.

3. Kauffman, R. S., J. L. Wolf, R. Finberg, J. S. Trier, and B. N. Fields. 1983. The sigma 1 protein determines the extent of spread of reovirus from the gastrointestinal tract of mice. Virology. 124:403410.

4. Tardieu, M., M. L. Powers, and H. L. Weiner. 1983. Age susceptibility to reovirus type 3 encephalitis: role of viral and host factors. Ann. Neurol. 13:602-7.

5. Rubin, D. H., M. J. Kornstein, and A. O. Anderson. 1985. Reovirus serotype 1 intestinal infection: a novel replicative cycle with ileal disease. J. Virol. 53:391-398.

6. Rubin, D. H., M. A. Eaton, and A. O. Anderson. 1986. Reovirus 
infection in adult mice: the virus hemagglutinin determines the site of intestinal disease. Microbial. Pathogen. 1:79-87.

7. Spriggs, D. R., R. T. Bronson, and B. N. Fields. 1983. Hemagglutinin variants of reovirus type 3 have altered central nervous system tropism. Science (Wash. DC). 220:505-507.

8. Rubin, D. H. 1987. Reovirus serotype 1 binds to the basolateral membrane of intestinal epithelial cells. Microbial. Pathogen. 3:215219.

9. Verdin, E. M., E. Maratos-Flier, C. R. Kahn, J. C. Sodoyez, F. Sodoyez-Goffaux, C. J. De Vos, S. P. Lynn, and B. N. Fields. 1987. Visualization of viral clearance in the living animal. Science (Wash. DC). 236:439-442.

10. Rubin, D. H., M. E. Eaton, and T. Costello. 1986. Reovirus type 1 is secreted into the bile. J. Virol. 60:726-8.

11. Bangaru, B., R. Morecki, J. H. Glaser, L. M. Gartwer, and M. S. Horwitz. 1980. Comparative studies of biliary atresia in human newborn and reovirus-induced cholangitis in weanling mice. Lab. Invest. 43:456-62.

12. Walters, M. N.-I., P. J. Leak, R. A. Joske, N. F. Stanley, and D. H. Perret. 1965. Brit. J. Exp. Pathol. 46:200-212.

13. Arias, I. M., W. B. Jakoby, H. Popper, D. Schachter, D. A. Shafritz. 1988. The Liver, Biology and Pathobiology. 2nd ed. Raven Press, New York. 394.

14. Panduro, A., F. Shalaby, F. R. Weiner, L. Biempica, M. Zern, and D. A. Shafritz. 1986. Transcriptional switch from albumin to alpha-fetoprotein and changes in transcription of other genes during carbon tetrachloride induced liver regeneration. Biochemistry 25:1414-1420.

15. Stowell, R. E., and C. S. Lee. 1950. Histochemical studies of mouse liver after single feeding of carbon tetrachloride. Arch. Pathol. 50:519-538.

16. Nakata, R., I. Tsukamoto, M. Miyoshi, and S. Kojo. 1985. Liver regeneration after carbon tetrachloride intoxication in the rat. Biochem. Pharmacol. 34:586-588.

17. Fabrikant, J. 1968. The kinetics of cellular proliferation in regenerating liver. Cell Biol. 36:551-565.

18. Ogawa, K., J. I. Suzuki, M. Narasaki, and M. Mori. 1984. Healing of focal injury in the rat liver. Am. J. Pathol. 119:158-167.

19. Fields, B. N., and M. I. Greene. 1981. Genetic and molecular mechanism of viral pathogenesis: implications for prevention and treatment. Nature (Lond.). 300:602-607.

20. Ramig, R. F., R. K. Cross, and B. N. Fields. 1977. Genome RNAs and polypeptides of reovirus serotypes 1,2 and 3. J. Virol. 22:726-733.

21. Smith, R. E., H. J. Zweernik, and W. K. Joklik. 1969. Polypeptide components of virion, top component and cores of reovirus type 3 . Virology. 39:791-812.

22. Lowry, O. H., A. L. Rosebrough, and R. J. Randall. 1951.
Protein measurement with the Folin phenol reagent. J. Biol. Chem. 193:265-275.

23. Hsu, S. M., L. Raine, and H. Fanger. 1981. The use of anti-avidin antibody and avidin biotin peroxidase complex in immunoperoxidase techniques. Am. J. Clin. Pathol. 75:816-821.

24. Duncan, M. R., S. M. Stanish, and D. C. Cox. 1978. Differential sensitivity of normal and transformed human cells to reovirus infection. J. Virol. 28:444-9.

25. Nemerow, G. R., M. E. McNaughton, and N. R. Cooper. 1985. Binding of monoclonal antibody to the Epstein-Barr virus (EBV)/CR2 receptor induces activation and differentiation of human B lymphocytes. J. Immunol. 135:3068-3073.

26. Lipkin, W. I., E. L. Battenberg, F. E. Bloom, and M. B. Oldstone. 1988. Viral infection of neurons can depress neurotransmitter mRNA levels without histologic injury. Brain. Res. 451:333-339.

27. Kavinskis, L. S., and M. B. Oldstone. 1989. Lymphocytic choriomeningitis virus selectively alters differentiated but not housekeeping functions: block in expression of growth hormone gene is at the level of transcriptional initiation. Virology. 168:232-235.

28. Enzan, H. 1985. Proliferation of Ito cells (fat-storing cells) in acute carbon tetrachloride liver injury: a light and electron microscopic autoradiographic study. Acta Pathol. Japan. 35:1301-1308.

29. David, H., and P. Reinke. 1987. The concept of the "perisinusoidal functional unit of the liver"-importance to pathological processes. Exp. Pathol. 32:193-224.

30. Bouwen, L. 1988. Proliferation and phenotype expression of non-parenchymal liver cells. Scand. J. Gastroenterol. 23(Suppl. 151):46-51.

31. Bukowski, J. F., B. A. Woda, S. Habu, K. Okumura, and R. M. Welsh. 1983. Natural killer cell depletion enhances virus synthesis and virus-induced hepatitis in vivo. J. Immunol. 131:1531-1538.

32. Kirn, A., J. P. Gut, A. Bingen, and A. M. Steffan. 1983. Murine hepatitis induced by frog virus III: a model for studying the effects of sinusoidal cell damage on the liver. Hepatology (Baltimore). 3:105111.

33. Hagman, N. W., A. M. Steffan, A. Kirin, and D. Keppler. 1985. Leukotrienes as mediators in frog virus 3-induced hepatitis in rats. Hepatology (Baltimore). 7:732-736.

34. Glaser, J. H., and R. Morecki. 1987. Reovirus type 3 and neonatal cholestasis. Semin. Liver Dis. 7:100-107.

35. Minuk, G. Y., N. Rascanin, R. W. Paul, P. W. Lee, K. Buchan, and J. K. Kelly. 1987. Reovirus type 3 infection in patients with primary biliary cirrhosis and primary sclerosing cholangitis. Hepatology (Baltimore). 5:8-13.

36. Brown, W. R., R. J. Sokol, M. J. Levin, A. Silverman, T. Tamaru, J. R. Lilly, R. J. Hall, and M. Cheney. 1988. Lack of correlation between infection with reovirus 3 and extrahepatic biliary atresia or neonatal hepatitis. J. Pediatr. 113:670-676. 